\title{
Balneotherapy of Psoriasis
}

\author{
Zoran GOLUŠIN ${ }^{1,2 *}$, Marina JOVANOVIĆ ${ }^{1,2}$, Biljana JEREMIĆ ${ }^{2,3}$, Siniša JOLIĆ ${ }^{3}$ \\ ${ }^{1}$ Faculty of Medicine, University of Novi Sad, Serbia \\ ${ }^{2}$ Clinic of Dermatovenereology Diseases, Clinical Center of Vojvodina, Novi Sad, Serbia \\ ${ }^{3}$ General Hospital Kikinda, Department of Dermatovenereology, Kikinda, Serbia \\ ${ }^{*}$ Correspondence: Dr. Zoran Golušin, E-mail:zgolusin@eunet.rs \\ DE GRUYTER
OPEN
}

UDC 616.517-085.838

\begin{abstract}
Application of different kinds of mineral waters and peloids on the skin exerts mechanical, thermal and chemical effects. Significant reduction of inflammation and increased differentiation of keratinocytes may explain why balneotherapy has positive clinical effects in psoriatic patients. In vitro models have shown that thermal water stimulates interleukin-2 production after cell stimulation by staphylococcal enterotoxin B, and reduces interleukin-4 secretion. After balneotherapy, a significant decrease in Psoriasis Area Severity Index (PASI), associated with a significant reduction of interleukin-8, Staphylococcus aureus colonization and enterotoxin $\mathrm{N}$, have been reported in patients with psoriasis. Mineral water was found to have inhibitory in vitro effects on substance P, TNF- release and antigen-induced cell degranulation. Immunomodulatory effects of water depend on its content. Sulfur waters have beneficial anti-inflammatory, keratolytic, and antipruriginous effects and also possess antibacterial and antifungal properties. The effectiveness of balneotherapy in the treatment of psoriasis has been reported in many studies conducted all over the world. The majority of studies were conducted at the Dead Sea coast. Investigations showed that balneotherapy factors are important therapeutic factors in the treatment of psoriatic patients. The first and only comparable study of this kind in Serbia, was conducted in Prolom Spa with satisfactory therapeutic results.
\end{abstract}

\section{Key words}

Balneology; Psoriasis; Mineral Waters; Treatment Outcome; Hydrotherapy; Review

Since the beginning of the time, man has searched for $\checkmark$ cures for diseases in nature. At first, he empiracally came to the conclusion what types and mechanism of action natural factors have on human beings, noticing that not all types of water, air and soil have equal curative effects. Over the time, newer scientific disciplines emerged, studying and comparing different effects of natural, emnvironmental, physical and chemical factors affecting human health. Balneology and balneoclimactology are among them.

\section{Historical Review}

The pionieer of modern dermatology, Ferdinand von Hebra (1816 - 1880), Austrian dermatologist, was the first to notice the benefits of mineral water on the psoriatic skin. However, at the same time he became aware that there was no place on Earth that would have a permanent reputation as highly effective in the management of diseases (1). Louis Duhring (1845 1913) also discussed the importance of water baths in the treatment of ichthyosis and pemphigus. There are written documents about beneficial effects of sulphur and alkaline waters in the treatment of psoriasis and eczema (2).

Almost all important mineral springs in Serbia have been used since Roman times. Upon their arrival to the Balkan peninsula, the Slavs inherited the practice of using the benefits of mineral springs and great majority of monasteries were founded by the rulers of that time in the vicinity of hot springs. There are not many data about the use of mineral waters in central and southern Serbia in the period of Turkish rule. Immediately after the liberation from the Turks rule, studies on mineral springs in Serbia began once again. In the early 1834 , Prince Miloš issued a written notice "to all officers of arms at whose territories there 
were mineral springs" to fill a number of jugs and send them to him in Kragujevac, whereby they would be sent to Vienna for analysis. These mineral waters were from Ribarska, Jošanička, Brestovačka, Višnjička and Palanačka spas. In 1851, Prince Aleksandar Karađorđević formed a Committee for Water Analysis and on its Application for therapeutical purposes. The task of this Committee was to visit and explore mineral springs, their therapeutic properties and write down what diseases they could cure, as well instructions for patients. Increased attention was given to spas by Austia-Hungary, as first descriptions and analyses of peloids originate from these territories in the second half of the $19^{\text {th }}$ century (3). The first law on spas, on mineral and thermal waters was passed in 1914, but due to the war it was put in action 15 years later. After the World War II, the position of spas and health resorts was regulated by the Health Protection Act, thereafter recognized as special health facilities. The first extensive report on the effects of balneotherapy on psoriasis in Serbia was done by Paravina et al. (4).

\section{Balneotherapy - nomenclature}

In order to avoid inconsistencies in the nomenclature and definitions of terms found in scientific literature referring to balneotherapy, Gomes et all. proposed a glossary that improves scientific communications (5):

Balneotherapy represents a set of methods and practices (bathing, drinking, inhalation, etc.), which use medical mineral waters, medical peloids and natural gasses for therapeutic purposes inside the facilities of the Health Resort Medicine Centers;

Hydrotherapy includes use of plain water (tap water) for therapy, through the external application of water and benefiting from its physical properties such as temperature, hydrostatic pressure, viscosity and electric conductivity; bathing, showers, water jets, underwater exercises, and body wraps are some methods of water application; hydrotherapy is commonly used along with pelotherapy;

Medical mineral waters are a group of underground waters, with special physical and chemical properties favorable to the human body, which can be used for prophylaxis and treatment. Mineral water is medically recognized by its special therapeutic properties, or simple health benefits that result from its mineral nature and content in oligoelements or other bio-essential elements;
Thermal waters are currently defined as mineral waters whose temperature, measured at the emergence site, exceeds in $4^{\circ} \mathrm{C}$ the mean local air temperature. The terms hyperthermal $\left(>38^{\circ} \mathrm{C}\right)$, mesothermal $(36-$ $\left.38^{\circ} \mathrm{C}\right)$ and hypothermal $\left(<36{ }^{\circ} \mathrm{C}\right)$ are used when the temperature of water exceeds $38^{\circ} \mathrm{C}$, ranges between $36-38^{\circ} \mathrm{C}$, is lower than $36^{\circ} \mathrm{C}$, respectively. Nowadays, the concept of thermal water is extended to all mineral waters which independently of the temperature at their emergence sites occur inside the area of the thermal resort and can be used for therapeutic purposes and consumed in the spa of the thermal resort. For therapeutic applications the temperature of mineral water is less important than its chemistry, since mineral water temperature is much more easily changed and controlled, particularly inside the spa;

Peloid is a maturated mud with healing and/ or cosmetic properties; peloids are natural products which are a mixture of mineral waters and finegrained organic and inorganic materials formed under the influence of geological, physical and/or biological and other processes which are used for therapeutic purposes as baths and packs; medical peloids are peloids with specific therapeutic properties recognized by national authorities who approve medicines or drugs based upon epidemiological studies, carried out by physicians specialized in medical hydrology and physiotherapy; medical peloids, hot or cold, should be applied under medical prescription and supervision, depending on the pathology that should be treated; Peloids are two-component systems, comprising a solid phase (inorganic/organic) and a liquid phase (mineral or sea water), the last stometimes including a gas phase (natural gasses, $\mathrm{SH}_{2}, \mathrm{CO}_{2}$, radon). Apart from dermatological diseases, peloid therapy is indicated for chronic rheumatic processes, degenerative osteoarthrosis, sequelae of osteo-articular injuries, fractures, dislocations, disorders following vasculopathies;

Thalassotherapy includes different medical preventive or curative benefits in marine or in highsaline lake environments, including practices such as: heliotherapy (controlled exposure to the sun), psammotherapy (controlled bathing in warm special sands, such as volcanic sand and biogenic carbonate sand) and algotherapy (controlled use of special marine algae), mud therapy (controlled external application 
of marine natural peloids), sea bathing, and any other substances of marine origin; peloids containing sea water are also used.

\section{Impact of balneotherapy factors on the skin}

It is known that application of mineral waters and peloids on the skin exerts mechanical, thermal and chemical effects. It reduces the thickness of the stratum corneum and stratum lucidum of the epidermis, increases the number of lymphocytes, histiocytes and eosinophilic granulocytes, increases skin permeability, reduces inflammation, improves microcirculation and immunity (3).

Thermal water can modulate cell membrane fluidity. Thus, a significant increase in membrane fluidity of fibroblasts, evidenced by decrease in fluorescence anisotropy, is observed. This property may be of interest because membrane fluidity has a significant impact on receptor expression, enzyme activity, pinocytosis, cell migration and cell transport processes (6). In vitro models have shown that thermal water stimulates interleukin-2 production after cell stimulation by staphylococcal enterotoxin B, and reduces interleukin- 4 secretion. It has also been demonstrated thar thermal water induces secretion of interferon $\gamma$ after cell tratment with anti CD3 monoclonal antibodies (7). A significant reduction of inflammation has been attributed to balneotherapy: inhibitory in vitro effects on substance $\mathrm{P}$, antigeninduced cell degranulation, as well as TNF- $\alpha$ (8, 9). Some data suggest that thermal water mediates inhibition of TNF- $\alpha$ induced E-selectin and ICAM-1 expression. The inhibition of such adhesion molecules is mediated by suppression of nuclear factor- $\kappa \mathrm{B}$ transcription factor, as it has been shown by in vitro model (10).

A study was conducted to evaluate effects of thermal water on keratinocyte differentiation. Three major findings were observed: water accelerates differentiation of normal human keratinocytes, increases expression of differentiation markers and formation of the upper layer; molecular mechanism responsible for mineral water effects on normal human keratinocytes was mediated by enhanced constitutive calcium cell entry that resulted in increased expression of involucrin and cytokeratins 1 and 10; this entry was due to overexpressed activated membrane receptor called transient receptor potential vanilloid 6 calcium channel (TRPV6). By accelerating differentiation and barrier restauration, this channel becomes a target responsible for beneficial effects of balneotherapy on skin lesions, such as psoriasis or atopic dermatitis (11).

After hydrotherapy, a significant decrease in Psoriasis Area Severity Index (PASI) was detected, associated with significant reduction of interleukin-8, enterotoxin $\mathrm{N}$ and colonization of Staphylococcus aureus (12).

The immunomodulatory effects of mineral waters depend on their composition. Waters with high contents of sodium bicarbonate and silicon dioxide reduce degranulation of basophils with suppressive effects on cytokine production. These in vitro immunomodulatory effect attributed to selenium, zinc and copper, may be compared with pharmacological effects of local immonomodulators such as imiquimod (13).

Sulfur waters may comprise various combinations of sulfur ions, water, and other ions. Sulfur waters exert beneficial anti-inflammatory, keratoplastic, and antipruritic effects and also possess antibacterial and antifungal properties. The therapeutic action of sulfur water is related to sulfur's keratolytic effect, resulting in peeling (14). On the immunologic level, sulfur-containing waters have inhibitory effecting on T-lymphocyte proliferative response to mitogens. It has been shown that sulfur waters inhibit the production and release of cytokines in human skin, such as IL-2 and IFN-gamma. According to some authors, these types of waters act mainly on the T-memory cells subset (15). Sulfur mineral waters, used for drinking, have antioxidant properties (16). It has been shown that exogenous hydrogen sulphide reduces clonal growth, cell proliferation and cell adhesion of human keratinocytes in psoriasis, but the role of endogenous sulfur in psoriasis is not well claryfied, since reduced level has been reported in patients with psoriasis as compared to normal subjects (17). Results obtained in experimental mouse model proved that hydrogen sulphide in sulfur mineral waters significantly reduces edema, inhibits the vascular phase of allergic contact dermatitis and increases plasma concentration of somatostatin. Since somatostatin is an antiinflammatory neuropeptide, Boros et al. showed that somatostatin plays an important role in the 
anti-inflammatory mechanism of action of sulfur medicinal water. In response to 21-day treatment of patients with psoriasis with sulfur medicinal water, dermal pool of dendritic cells almost disappeared and the epidermal populations of Langerhans cells showed normal distribution. Plasma concentration of somatostatin in psoriatic patients was higher than in healthy volunteers, and its level showed a further increase in response to bath treatment (18).

In the treatment of psoriasis, a combination of two balneotherapeutic active principles, namely mineral waters and peloids, is frequently used. Thus, Figures 1 and 2, show our patient after three weeks of treatment in Rusanda Spa (19).

\section{Clinical effectiveness of balneotherapy in psoriasis}

Psoriasis is among the diseases that are successfully treated with balneotherapy, and its therapy is still the object of numerous studies, particularly those that combine balneotherapy with other therapeutic modalities, eg. phototherapy (13). The effectiveness of balneotherapy in the treatment of psoriasis has been reported in many studies conducted in the world. One study was conducted in Prolom Spa (Serbia), with satisfactory therapeutic results. The study included 35 patients. After one week of using mineral waters and peloids, the PASI score improved by $26.69 \%$, after 2 weeks by $28.60 \%$, after 3 weeks by $38.75 \%$ and after 4 weeks by $46.42 \%$; erythema persisted during the first week; significant improvement was noticed after 4 weeks treatment, when PASI was reduced by $41.05 \%$. The effects of treatment on infiltration was noticed after the first and the second week when PASI was reduced by $26.13 \%$ and $27.51 \%$, respectively, and it improved as treatment went on; desquamation was significantly decreased after seven days of treatment by $38.26 \%$; females showed better response to therapy and improvement of PASI in the first two weeks of treatment, whereas males responded better in the second two weeks. Prolom water is in the category of sodium hydrocarbonate, silicon, alkaline, oligomineral and hypothermic waters (4).

In Argentina, 55 patients with psoriasis were treated with mineral baths, peloids and/or algae at the Copahue Thermal Complex. The patients took mineral baths twice a day, during 10 days on average. They showed improvement in terms of reduced erythema and desquamation, which was confirmed

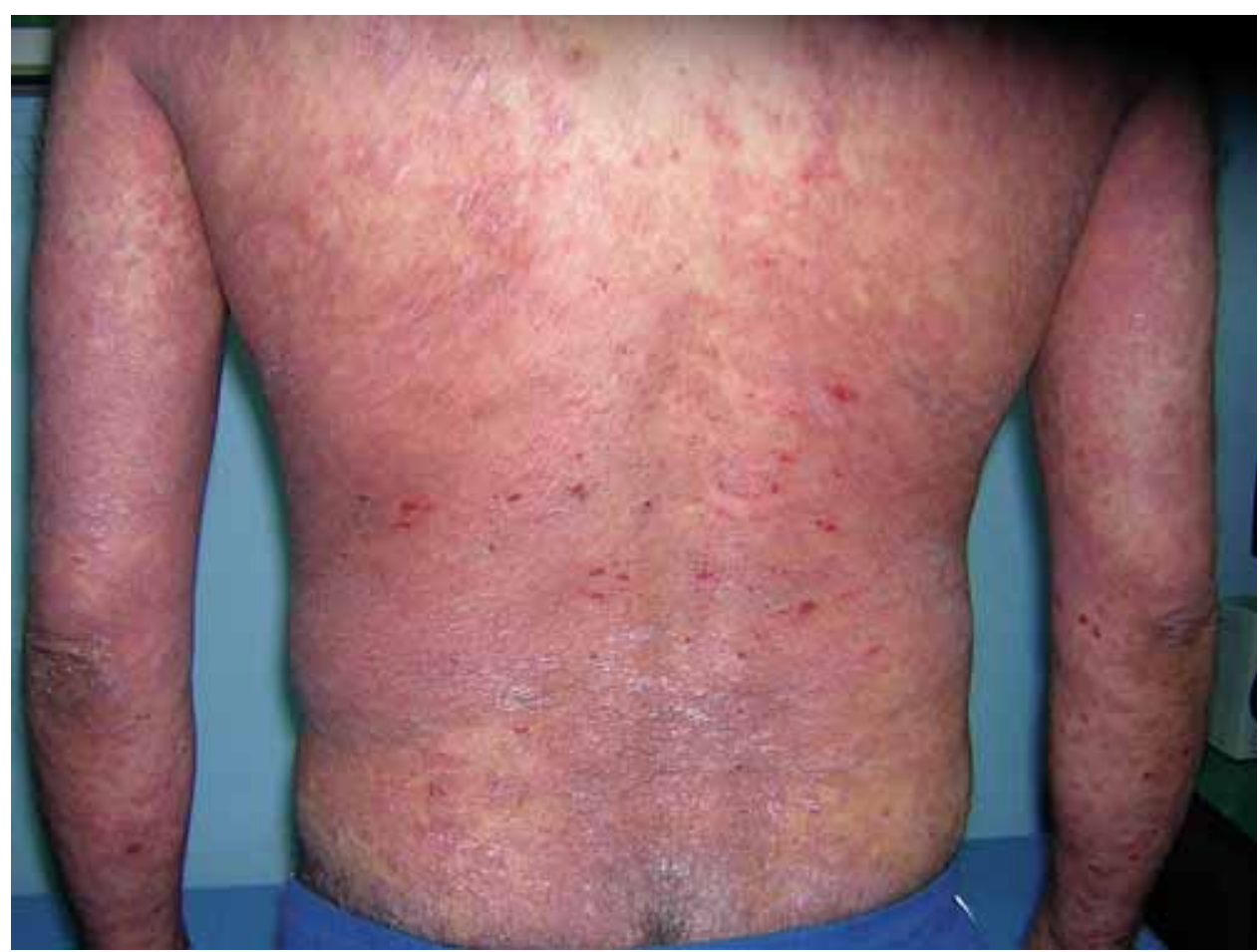

Figure 1. Our patient before treatment in Rusanda Spa 


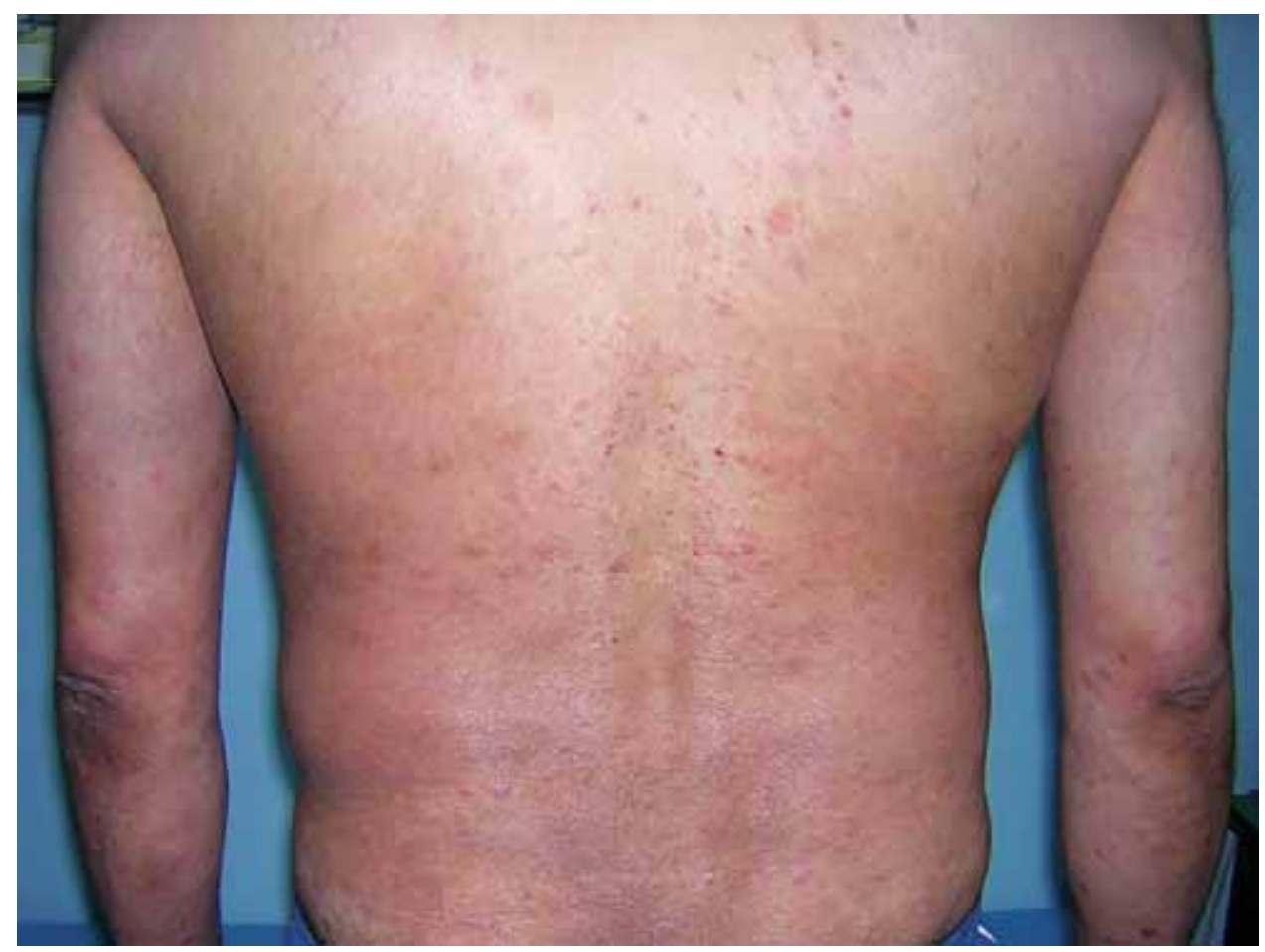

Figure 2. Our patient after three weeks of treatment in Rusanda Spa

by histopathological analysis (19). Beneficial effects of balneotherapy have been reported in Bulgaria, with hypothermal water: in Jagoda Spa 54 patients with vulgar psoriasis underwent a combination of balneotherapy, topical dithranol and phototherapy (20-minute baths, then 1.5 to $3 \%$ dithranol for 10 to 30 minute and exposure to UV rays with wavelengths of $300-340 \mathrm{~nm}$ from 1 to 20 minutes); three weeks later, $73.3 \%$ of patients showed a significant improvement of skin lesions (21). A study conducted in Marikostinovo Spa included 100 patients treated with a combination of mineral water and sulfide peloids; both procedures lasted 10 to 20 minutes daily, during three weeks; $3 \%$ of respondents showed complete regression of skin lesions, in 5\% there was a significant improvement, $83 \%$ showed moderate improvement, in $5 \%$ the therapy showed no effects and in $4 \%$ of patients the condition got worse (22).

A large number of investigations worldwide have led to the recognition of beneficial effects of balneotherapy and heliotherapy for chronic stationary psoriasis. The best results were achieved at the Dead Sea in Israel, which is characterized by high salinity (about 30\%), high concentration of minerals in the air (magnesium, bromide and other minerals) and more than 330 sunny days per year. The most comprehensive study at the Dead Sea was conducted in 1995, including 1.448 patients with psoriasis. After four weeks of bathing in sea water and sun exposure, $88 \%$ of patients showed improvement. The degree of improvement varied from $80 \%$ to $100 \%$ reduction in PASI score (23). Another prospective study at the Dead Sea included 100 patients with psoriasis, who were treated during four weeks; in $75 \%$ of patients there was a complete regression of skin lesions; after the end of therapy, $68 \%$ of these patients were in complete remission during the next four months, $43 \%$ of patients were in remission after six months, and in $10 \%$ of patients complete remission lasted for eight months after the treatment. By monitoring the length of remission after the treatment, it was observed that this period was shorter than after some other forms of therapy, such as cyclosporine or PUVA. Moreover, the efficacy of heliotherapy during four weeks was higher than with UVB phototherapy (24). In patients who bathed in Dead Sea and underwent narrowband UVB (wavelengths of $311 \mathrm{~nm}$ ), phototherapy three to five times per week, after 35 treatments, PASI score decreased from 17.7 to 5.2 ; the most common side effect of this therapy was rash, found in $87 \%$ of 
patients; after the treatment, $55 \%$ of patients had recurrence after six months, and $68 \%$ of patients after one year (25). Using retrospective data, David et al. concluded that guttate and chronic plaque psoriasis showed the highest benefit from balneotherapy at the Dead Sea; moderate improvement was seen in flexural psoriasis and palmoplantar psoriasis; scalp and erythrodermic psoriasis were mostly unresponsive, whereas in generalized pustular psoriasis balneotherapy was contraindicated (26).

Harari et al. conducted a prospective nonrandomized study on the efficiency of balneotherapy at the Dead Sea including 740 psoriatic patients. Complete clearance after 4 weeks of natural balneotherapy and heliotherapy (controlled exposure to sun) was reported in $70 \%$ of patients (27). A retrospective analysis included 605 patients treated at the Dead Sea for plaque psoriasis. Patients with earlyonset of psoriasis (under 40 years of age), achieved better results following Dead Sea climatotherapy (28). A prospective non-randomized study on the efficiacy of climatotherapy at the Dead Sea for pediatric-onset psoriasis vulgaris, studied 17 children between 10 and 18 years of age; six months after the treatment period, 12 patients were relapse-free, and five had a mild relapse; improvement in PASI score over $75 \%$ and between $50 \%$ and $75 \%$ was noted in $35.3 \%$ and $29.4 \%$ of patients, respectively (29). Studying skin biopsies of psoriatic patients before and after climatotherapy at the Dead Sea coast, Hodak et al. reported significant reduction in the number of activated T-lymphocytes in the epidermis (depletion of more than $90 \%$ of $\mathrm{CD} 3$ + and $\mathrm{CD} 25$ + cells) and in the dermis (depletion of $69.4 \%$ of CD3 + and of $77.4 \% \mathrm{CD} 25$ + cells); there was also a marked reduction in HLA-DR expression in keratinocytes (30).

A combination of three beneficial factors for psoriasis: sun, sea water and air, has been studied in patients with psoriasis at the Black Sea in Bulgaria. In a group of 177 patients, the therapy lasted 20 days and covered sun exposure of $5-6$ hours and bathing in the sea water from 5-15 minutes a day; complete regression of skin lesions was found in $68.9 \%$ of patients, significant improvement in $17.1 \%$ and moderate improvement in $9.5 \%$ of patients; only $4.5 \%$ of patients did not respond to the therapy: patients with acute guttate type improved more quickly compared to those with other types of psoriasis (plaque, geographical, palmo-plantar, inversa and inveterata) (31).

In German rehabilitation centers, balneophototherapy is a phototherapeutic modality, a combination of salt water baths and artificial UV radiation. A prospective, randomized, blind, right/left comparison investigating the efficacy of balneophototherapy in psoriasis with highly concentrated salt water versus tap water, was performed in patients with chronic plaque psoriasis: one elbow was soaked in $24 \% \mathrm{NaCl}$ solution and the other in tap water, subsequently, broadband UVB irradiation was administered on the both. Balneophototherapy was performed 4 times weekly with a total of 30 treatments; a highly significant $(\mathrm{p}<0.001)$ decrease of the baseline score was observed after 30 treatments; however, there was no significant $(\mathrm{p}>0.5)$ difference in clearance of lesions between sites soaked in salt water and tap water (32).

During balneotherapy of psoriasis, some studies have investigated the influence of natural factors on psychosomatic and somatopsychological factors of patients with psoriasis. About $45 \%$ of psoriatic patients feel inadequate and are socially isolated $(p<0.001)$. Depressive disorders were detected in $66 \%$ of patients with psoriasis prior to a 20-day thalassotherapy at the Bulgarian Seaside. Common complaints among patients with different levels of depression were the following: fatigue (57\%), bitterness (50\%) and sleeping disorders (46\%). After the course of treatment, $63.6 \%$ of patients with depression showed no psychological abnormalities (euthymic state) (33).

\section{Conclusion}

Due to the multidisciplinary character of balneotherapy and its applications in patients with psoriasis, it is necessary to consider therapeutic methods used in balneotherapy complementary to the well known methods used in heath resorts. The best effects are achieved when these methods are combined. Further controlled studies are required to ascertain the best treatment regimens and duration of their administration.

\section{Abbreviations}

PASI - Psoriasis Area Severity Index

TNF- $\alpha$ - tumor necrosis factor-alpha 
$\mathrm{SH}_{2}$ - hydrogen sulphide

$\mathrm{CO}_{2}$ - carbon dioxide

ICAM-1 - intercellular adhesion molecule-1

TRPV6 - transient receptor potential

vanilloid-6

IL-2 - interleukin-2

IFN - interferon

PUVA - psoralen plus ultraviolet-A light

UVB - ultraviolet-B light

\section{References}

1. Hebra F. On diseases of the skin. Vol 2. London: New Sydenham Society; 1868. p. 31-5.

2. Duhring LA. A practical treatise on diseases of the skin. Philadelphia: Lippincott; 1883. p. 102.

3. JovanovićT, urednik. Balneoklimatologija. Beograd: Medicinski fakultet, Univerzitet u Beogradu; 1994.

4. Paravina M, Stepanović M, Racić G. Balneotherapy effectively acts on symptoms of psoriasis vulgaris. Central Eastern European Dermato Venereological Association (CEEDVA) Bulletin 2002;4:70-2.

5. Gomes C, Carretero MI, Pozo M, Maraver F, Cantista P, Armijo F, et al. Peloids and pelotherapy: historical evolution, classification and glossary. Appl Clay Sci 2013;75-76:28-38.

6. Tillman TS, Cascio M. Effects of membrane lipids on ion channel structure and function. Cell Biochem Biophys 2003;38:161-90.

7. Portales P, Aries MF, Licu D, Pinton J, Hernandez-Pion C, Gall $\mathrm{Y}$, et al. Immunomodulation induced by Avene spring water in Th-1- and Th2-dependent cytokine production in healthy subjects and atopic dermatitis patients. Skin Pharmacol Appl Skin Physiol 2001;14:234-42.

8. Joly F, Charveron M, Aries MF, Bidault J, Kahhak L, Beauvais $\mathrm{F}$, et al. Effect of Avene spring water on the activation of rat mast cell by substance P or antigen. Skin Pharmacol Appl Skin Physiol 1998;11:111-6.

9. Boisnic S, Branchet-Gumila MC, Segard C. Inhibitory effect of Avene spring water on vasoactive intestinal peptide-induced inflammation in surviving human skin. Int J Tissue React 2001;23:89-95.

10. Castex-Rizzi N, Charveron M, Merial-Kieny C. Inhibition of TNF-alpha induced-adhesion molecules by Avene Thermal Spring Water in human endothelial cells. J Eur Acad Dermatol Venereol 2011;25(Suppl 1):6-11.

11. Lehen'kyi V, Vandenberghe M, Belaubre F, Julie S, CastexRizzi N, Skryma R, et al. Acceleration of keratinocyte differentiation by transient receptor potential vanilloid (TRPV6) channel activation. J Eur Acad Dermatol Venereol 2011;25(Suppl 1):12-8.

12. Casas C, Ribet V, Alvarez-Georges S, Sibaud V, Guerrero D, Schmitt AM, et al. Modulation of Interleukin-8 and staphylococcal flora by Avene hydrotherapy in patients suffering from chronic inflammatory dermatoses. J Eur Acad Dermatol Venereol 2011;25(Suppl 1):19-23.

13. Ghersetich I, Freedman D, Lotti T. Balneology today. J Eur Acad Dematol Venereol 2000;14:346-8.
14. Matz H, Orion E, Wolf R. Balneotherapy in dermatology. Dermatol Ther 2003;16:132-40.

15. Kazandjieva J, Grozdev I, Darlenski R, Tsankov N. Climatotherapy of psoriasis. Clin Dermatol 2008;26(5):477-85.

16. Benedetti S, Benvenuti F, Nappi G, Fortunati NA, Marino L, Aureli T, et al. Antioxidative effects of sulfurous mineral water: protection against lipid and protein oxidation. Eur J Clin Nutr 2009;63:106-12.

17. Basavaraj KH, Darshan MS, Shanmugavelu P, Rashmi R, Mhatre AY, Dhanabal SP, et al. Study on the levels of trace elements in mild and severe psoriasis. Clin Chim Acta 2009;405:66-70.

18. Boros M, Kemeny A, Sebok B, Bagoly T, Perkecz A, Petohazi $Z$, et al. Sulphurous medicinal waters increase somatostatin release: it is a possible mechanism of anti-inflammatory effect of balneotherapy in psoriasis. Eur J Integr Med 2013;5:109-18.

19. Golušin Z, Jovanović M, Magda N, Stojanović S, Matić M, Petrović A. Effects of Rusanda spa balneotherapy combined with calcipotriol on plaque psoriasis. Vojnosanit Pregl 2014; in press.

20. Ubogui J, Stengel FM, Kien MC, Sevinsky L, Rodriguez-Lupo L. Thermalism in Argentina. Alternative or complementary dermatologic therapy. Arch Dermatol 1998;134(11):1411-2.

21. Spirov G, Zlatkov N, Durmishev A. Balneotherapy. In: Zlatkov N. Climatotherapy of skin diseases. Sofia: Medicina i Fizkultura, 1989;146-76.

22. Tsankov NK, Kamarashev J. Spa therapy in Bulgaria. Clin Dermatol 1996;14:675-8.

23. Abels DJ, Rose T, Bearman JE. Treatment of psoriasis at the Dead Sea dermatology clinic. Int J Dermatol 1995;34:134-7.

24. Shani J, Harari M, Hristakieva E, Seidl V, Bar-Giyora J. Dead-Sea climatotherapy versus other modalities of treatment for psoriasis: comparative cost-effectiveness. Int J Dermatol 1999;38:252-62.

25. Schiffner R, Schiffner-Rohe J, Wolfl G, Landthaler M, Glassl A, Walther TH, et al. Evaluation of a multicentre study of synchronous application of narrowband ultraviolet B phototherapy (TL-01) and bathing in Dead Sea salt solution for psoriasis vulgaris. Br J Dermatol 2000;142:740-7.

26. David M, Efron D, Hodak E, Even-Paz Z. Treatment of psoriasis at the Dead Sea: why, how and when? Isr Med Assoc J 2000;2(3):232-4.

27. Harari M, Shani J. Demographic evaluation of successful antipsoriatic climatotherapy at the Dead Sea (Israel) DMZ Clinic. Int J Dermatol 1997;36(4):304-8.

28. Harari M, Czarnowicki T, Fluss R, Ruzicka T, Ingber A. Patients with early-onset psoriasis achieve better results following Dead Sea climatotherapy. J Eur Acad Dermatol Venereol 2012;26(5):554-9.

29. Ben-Amitai D, David M. Climatotherapy at the Dead Sea for pediatric-onset psoriasis vulgaris. Pediatr Dermatol 2009;26(1):103-4.

30. Hodak E, Gottlieb AB, Segal T, Politi Y, Maron L, Sulkes J, et al. Climatotherapy at the Dead Sea is a remittive therapy for psoriasis: combined effects on epidermal and immunologic activation. J Am Acad Dermatol 2003;49(3):451-7.

31. Kiriakova N, Etugov D, Popov J, Kazandjieva J. Thalassotherapy of psoriatic patients in Bulgaria. Central Eastern European Dermato Venereological Association (CEEDVA) Bulletin 2002;4:67-9. 
32. Gambichler T, Rapp S, Senger E, Altmeyer P, Hoffmann K. Balneophototherapy of psoriasis: highly concentrated salt water versus tap water-a randomized, one blind, right/left comparative study. Photodermatol Photoimmunol Photomed 2001;17:22-5.
33. Popov J, Kiriakova N, Dencheva R, Kazandjieva J, Fercheva A, Tsankov N. Some psychosomatic aspects of the patients with psoriasis vulgaris treated at the Bulgarian seaside. Central Eastern European Dermato Venereological Association (CEEDVA) Bulletin 2002;4:29-31.

\section{Balneoterapija psorijaze}

\section{Sažetak}

Istorijat. Smatra se da je pionir u korišćenju mineralne vode $\mathrm{u}$ terapijske svrhe $\mathrm{u}$ dermatologiji austrijski dermatolog Ferdinand von Hebra. On je primetio blagotvornost primene mineralne vode $\mathrm{u}$ terapiji psorijaze, ali je istovremeno uočio da ne postoji takvo mesto na svetu koje može da dobije stalnu reputaciju u lečenju ove bolesti. U Srbiji gotovo da nema značajnijeg izvorišta mineralne vode, a da nisu ostali dokazi o njegovom korišćenju u rimsko doba, ali nema podataka da je voda korišćena u dermatološke svrhe. $\mathrm{Za}$ period pod turskom vladavinom nema mnogo podataka o korišćenju mineralnih voda u Centralnoj i Južnoj Srbiji. Odmah po oslobađanju od Turaka, počinje izučavanje voda u Srbiji. S obzirom na veću pažnju koju je Austrougarska posvećivala banjskim lečilištima, prvi opisi i analize peloida sa ovih prostora potiču iz druge polovine 19. veka.

Uticaj balneoterapijskih činilaca na kožu. Poznato je da mineralne vode i peloid aplikovani na kožu ispoljavaju mehaničko, termičko i hemijsko dejstvo. Rezultati dosadažnjih istraživanja pokazali su da primena mineralnih voda i peloida smanjuje debljinu stratuma korneuma i stratuma luciduma u epidermisu, povećava broj limfocita, histiocita i eozinofilnih granulocita, povećava permeabilnost kože, redukuje aktivnost zapaljenskih procesa, poboljšava mikrocirkulaciju i povoljno deluje na imunske procese. Uticaj na diferencijaciju keratinocita objašnjen je istraživanjima koja su vršena u poslednjih nekoliko godina. Značajno smanjenje PASI (Psoriasis Area Severity Index) skora

kod obolelih od psorijaze povezuje je sa značajnim smanjenjenjima nivoa intreleukina 8, kolonizacije bakterijom Staphylococcus aureus i endotoksina N posle balneoterapije. Imunomodulirajući efekat mineralnih voda zavisi od njihovog sastava, a posebno mesto imaju sumporne vode koje deluju antiinflamatorno, keratolitički, antipruriginozno, antibakterijski i antifungalno.

Klinička efikasnost balneoterapije kod obolelih od psorijaze. Efikasnost balneoterapije kod obolelih od psorijaze opisana je u studijama širom sveta. U Srbiji je obavljeno ispitivanje čiji su rezultati pokazali $\mathrm{da}$ je tronedeljna terapijska primena mineralne vode i peluda u Prolom Banji dovela do smanjenja PASI skora kod 38,75\% ovako lečenih osoba. U Argentini je balneoterapija dala dobre rezultate $u$ smanjivanju deskvamacije i eritema na koži, što je potvrđeno patohistološkim nalazom. U banjama u Bugarskoj, osim kombinacije sulfidnih voda i peloida, balneoterapijski činioci kombinovani su sa ditranolom i fototerapijom što je kod $73,3 \%$ pacijenata dovelo do značajnog poboljšanja promena na koži. Veliki broj istraživanja u svetu je posvećen ispitivanju uticaja balneoterapije i helioterapije na psorijazu. Najbolji rezultati postignuti su na Mrtvom moru. Rezultati dosadašnjih istraživanja pokazali su da su činioci spoljašnje sredine istovremeno značajni terapijski faktori za obolele od psorijaze. Najbolji efekti se postižu kada se ovi činioci kombinuju sa ostalim vidovima terapije.

\section{Ključne reči}

Balneologija; Psorijaza; Mineranlne vode; Ishod lečenja; Hidroterapija; Pregled literature 